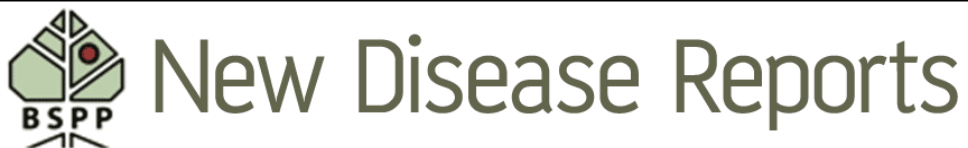

\title{
First confirmed report of bacterial wilt of tomato in Georgia caused by Ralstonia solanacearum
}

\author{
G. Mepharishvili ${ }^{1} *$, Z. Sikharulidze ${ }^{1}$, R. Thwaites ${ }^{2}$, T. Tsetskhladze $^{1}$, R. Dumbadze $^{1}$, M. Gabaidze ${ }^{1}$ and M. Muradashvili $^{1}$ \\ ${ }^{1}$ Shota Rustaveli State University Scientific Centre, 90, Tavisupleba str., Kobuleti 6200, Georgia; ${ }^{2}$ Food and Environment \\ Research Agency, Sand Hutton, York, YO41 1LZ, UK
}

*E-mail: galinameparishvili@yahoo.com

Received: 27 Jan 2012. Published: 05 Apr 2012. Keywords: Solanum lycopersicon, bacterial diseases

In June of 2010 a wilt disease affecting tomato seedlings was reported by farmers in Chkhorotsku region, Western Georgia, causing up to $100 \%$ plant loss. Anecdotal reports suggested that eggplant and sweet pepper plants on farms in the same region were also infected. Similar symptoms, indicative of bacterial wilt caused by Ralstonia solanacearum which included wilting and vascular discolouration (Fig. 1) were also observed in 2010 by farmers in Kutaisi region, and the disease was observed in tomato plants examined in a plant health clinic in Kutaisi in July 2011. Symptoms observed in these specimens included wilting of entire plants (Fig. 2) and vascular discolouration (Fig. 3). Samples were taken for further analysis at Shota Rustaveli State University Scientific Centre in Georgia and the Food and Environment Research Institute (Fera), UK.

Initial diagnosis was carried out at Shota Rustaveli State University by amplifying a DNA extract obtained from infected material with primers OLI1 and Y2 (Seal et al., 1993), which indicated the presence of $R$. solanacearum. An isolate was also obtained from infected material at Fera, which was identified as $R$. solanacearum by real-time PCR amplification as described by Weller et al., (2000). Analysis of whole cell fatty acids was also undertaken (Stead, 1992) which identified the organism as $R$. solanacearum with a similarity index of 0.856 . Tomato seedlings inoculated with this isolate exhibited wilt symptoms five days after inoculation, and the bacterium was successfully re-isolated from wilted tomatoes. Our investigations have therefore confirmed that $R$. solanacearum is present and causing wilt disease of tomato in Georgia. This is the first report of bacterial wilt caused by $R$. solanacearum in Georgia substantiated by isolation and identification of the bacterium. The presence on tomato is highly significant as this is a valuable crop for farmers in many regions across Georgia.

\section{Acknowledgements}

This study was supported by a grant from the ISTC \#G-1775p and the Biological Engagement Programme of the UK Ministry of Defence. The authors would like to thank Colleagues from Fera for studies and suggestions

\section{References}

Seal SE, Jackson LA, Young JPW, Daniels MJ, 1993. Differentiation of Pseudomonas solanacearum, Pseudomonas syzygii, Pseudomonas pickettii and the blood disease bacterium by partial 16S rRNA sequencing: construction of oligonucleotide primers for sensitive detection by polymerase chain reaction. Microbiology 139, 1587-1594. [doi:10.1099/00221287-139-7-1587]

Stead DE, 1992. Grouping of plant-pathogenic and some other Pseudomonas spp. by using cellular fatty acid profiles. International Journal of Systematic Bacteriology 42, 281-295.

[doi:10.1099/00207713-42-2-281]

Weller SA, Elphinstone JG, Smith NC, Boonham N, Stead DE, 2000. Detection of Ralstonia solanacearum strains with a quantitative, multiplex, real-time, fluorogenic PCR (TaqMan) assay. Applied and Environmental Microbiology 66, 2853-2858. [doi:10.1128/AEM.66.7.2853-2858.2000]
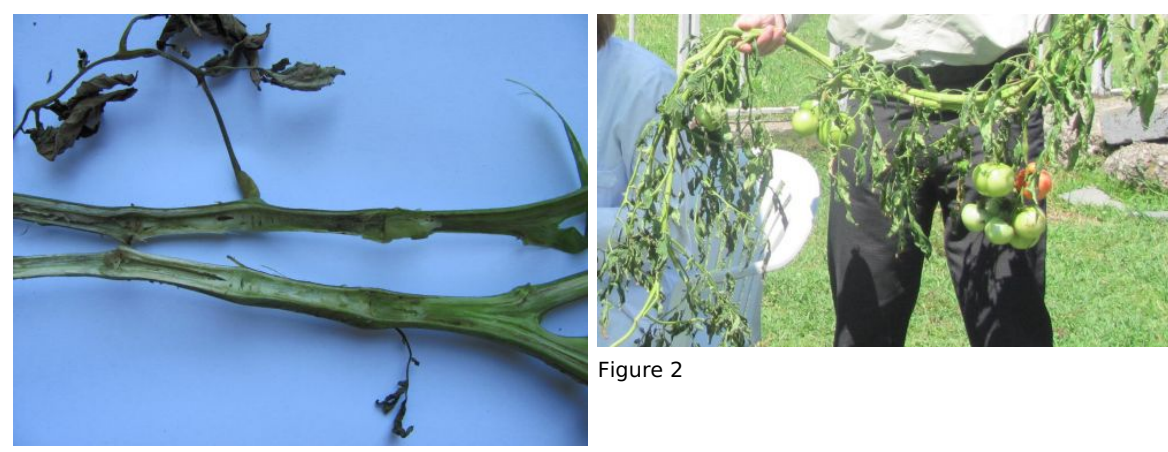

Figure 2

Figure 1

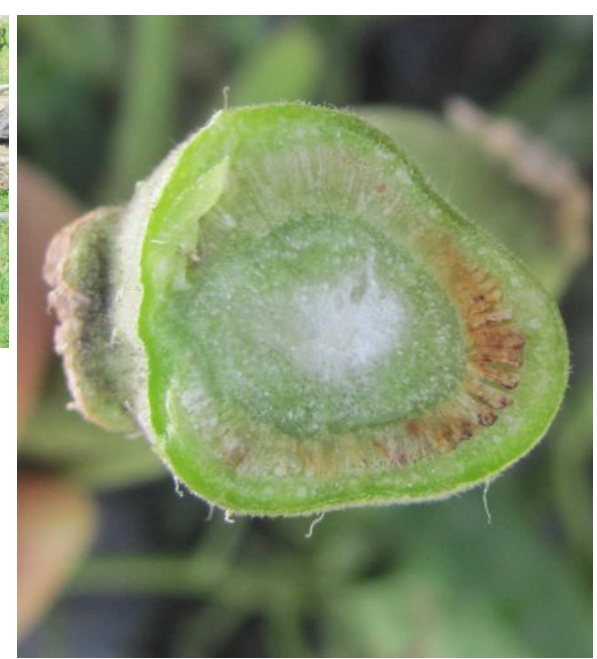

Figure 3

To cite this report: Mepharishvili G, Sikharulidze Z, Thwaites R, Tsetskhladze T, Dumbadze R, Gabaidze M, Muradashvili M, 2012. First confirmed report of bacterial wilt of tomato in Georgia caused by Ralstonia solanacearum. New Disease Reports 25, 16.

[doi:10.5197/j.2044-0588.2012.025.016] (C) 2012 The Authors

This report was published on-line at www.ndrs.org.uk where high quality versions of the figures can be found. 